\title{
EVALUASI PENERAPAN GLOBALLY HARMONIZED SYSTEM (GHS) SEBAGAI PENGENDALIAN BAHAN KIMIA DI PT. PUPUK KALIMANTAN TIMUR
}

\author{
Pamela Dewi Widuri*, Mulyono* \\ Departemen Keselamatan dan Kesehatan Kerja \\ *Fakultas Kesehatan Masyarakat Universitas Airlangga \\ Email : pamela.dewiduri@gmail.com
}

\begin{abstract}
ABSTRAK
Salah satu industri yang memiliki efek bahaya tinggi adalah industri kimia, baik yang ditimbulkan dari bahaya bahan kimia maupun dalam proses produksi. Penggunaan berbagai macam bahan kimia dalam jumlah besar maupun kecil apabila tidak memperhatikan aspek keselamatan dan kesehatan kerja maka yang dapat terjadi adalah dampak buruk yang mengakibatkan kecelakaan, baik terhadap manusia, kerusakan bahan, lingkungan sekitar, ataupun terganggunya proses produksi didalam kelangsungan operasional perusahaan. Maka dari itu setiap pabrik harus memiliki pengendalian dan melakukan pencegahan kecelakaan dengan tepat. Globally Harmonized System merupakan salah satu pengendalian bahan kimia untuk standarisasi kriteria dan mengharmonisasikan sistem klasifikasi bahaya bahan kimia serta mengkomunikasikan informasi tersebut pada safety data sheet (SDS)/ lembar data keselamatan dan label bahan kimia (LDK) sesuai dengan Peraturan Menteri Perindustrian Nomor 87/M-IND/PER/9/2009. Penelitian ini bersifat observasional, dengan pendekatan cross sectional. Dengan populasi dan sampling seluruh total bahan kimia yang digunakan sebagai bahan baku dan disimpan di gudang bahan kimia PT. Pupuk Kalimantan Timur. Data dianalisis secara deskriptif menggunakan tabulasi dan frekuensi Hasil penelitian menunjukkan tingkat penerapan Globally Harmonized System di PT. Pupuk Kalimantan Timur dalam kategori "baik".
\end{abstract}

Kata kunci: Bahan Kimia, Pabrik, Pengendalian, Kecelakaan Kerja, Sistem Harmonisasi Global

\begin{abstract}
One of the industries that have the effect of high danger is the chemical industry, both arising from chemical hazards as well as in the production process. The use of various chemicals in large quantities or small, if not pay attention to safety and health aspects of it that can happen is the bad effects that lead to accidents, both to human, material damage, the environment, or disruption of the production process in the company's operational continuity. Therefore each plant must have the control and prevention of accidents appropriately. Globally Harmonized System is one of the control of chemicals to standardize criteria and harmonized system of classification of chemical hazards and communicate that information in the safety data sheet (SDS) and labeling of chemicals in accordance with the Regulation of the Minister of Industry No. 87 / M -IND / PER / 9/2009. This study is observational with cross sectional approach. With the total population and sampling chemicals used as raw materials and chemicals stored in the warehouse PT. Pupuk Kalimantan Timur. Data were analyzed descriptively using frequency tabulation and results showed the level of application of the Globally Harmonized System in PT. Pupuk Kalimantan Timur in the category "good".
\end{abstract}

Keywords : Chemical, Factory, Control, Occupational Accident, Globally Harmonized System. 


\section{PENDAHULUAN}

Industri kimia merupakan salah satu industri yang memiliki efek bahaya tinggi. Efek bahaya yang ditimbulkan diantaranya adalah ledakan, kebakaran, dan keracunan serta bahaya dalam proses produksinya yang mencakup pengolahan bahan kimia dan penyimpanan bahan kimia yang dapat menumbulkan bahaya besar. (Bouloiz, 2010)

WHO memperkirakan sebanyak 150.000 bahan kimia telah beredar, dan bertambah sekitar 200 sampai 1000 jenis baru bahan kimia setiap tahunnya dan diperkirakan terdapat 100.000 bahan kimia yang digunakan dalam berbagai industri di mana sekitar 12.000 diantaranya diketahui berdampak negatif terhadap kesehatan manusia atau pekerja. Banyak diantara bahan kimia tersebut yang keamanan penggunaannya belum terjamin, bahkan belum diketahui efeknya, tetapi telah banyak digunakan dalam proses industri. Penggunaan bahan ini dalam jangka waktu pendek dan terlebih lagi dalam jangka waktu panjang dapat menyebabkan gangguan kesehatan pada pekerja, seperti menimbulkan penyakit dan keganasan yang berakibat fatal (Suriya, 2003).

Kegiatan Industri dalam mengolah, menyimpan, mengedarkan, mengangkut dan mempergunakan bahan-bahan kimia berbahaya akan terus meningkat sejalan dengan perkembangan pembangunan sehingga berpotensi untuk menimbulkan bahaya besar bagi industri, tenaga kerja, lingkungan maupun sumber daya lainnya.

Penggunaan berbagai macam bahan kimia dalam jumlah besar maupun kecil apabila tidak memperhatikan aspek keselamatan dan kesehatan kerja maka yang dapat terjadi adalah dampak buruk yang mengakibatkan kecelakaan, baik terhadap manusia, kerusakan bahan, lingkungan sekitar, ataupun terganggunya proses produksi didalam kelangsungan operasional perusahaan. Kecelakaan yang dapat ditimbulkan akan menyebabkan kerugian perusahaan baik terhadap manusia, bahan kimia tersebut, dan lingkungan sekitar yang apabila dikalkulasi biaya yang dikeluarkan untuk menangani hal tersebuat apabila terjadi kecelakaan lebih besar dari pada biaya pencegahannya.

Berdasarkan data kecelakaan PT. Pupuk Kalimantan Timur tahun 2015, kecelakaan yang terjadi pada karyawan PT. Pupuk Kalimantan Timur akibat bahan kimia sebesar $36,8 \%$ pada tahun 20072015. Penyebab terbesar kecelakaan di Indonesia, berdasarkan data dari Pusat Kesehatan Kerja tahun 2010 sebanyak 80$85 \%$ penyebab kecelakaan kerja di industri karena kelalaian atau kesalahan faktor manusia. Berdasarkan peristiwa 
yang terjadi pada kasus diatas menggambarkan bahwa keadaan industri kimia memiliki efek bahaya yang tinggi dengan memakan jumlah korban jiwa yang banyak dalam hampir setiap kasusnya. Maka dari itu setiap pabrik harus memiliki pengendalian dan melakukan pencegahan kecelakaan dengan tepat.

Menurut Ramli, dalam melakukan pengendalian terhadap kecelakaan kerja dapat melakukan beberapa hierarki pengendalian yaitu pengendalian eliminasi, substitusi, rekayasa teknik, administrasi, dan alat pelindung diri (APD). Pengendalian administrasi merupakan salah satu cara dalam upaya pengendalian bahaya dari bahan kimia yang digunakan di industri pada umumnya, salah satunya adalah dengan menerapkan GHS (Globally Harmonized System) atau yang dikenal dengan Sistem Harmonisasi Global yang telah diatur dalam Peraturan Menteri Perindustrian Republik Infonesia Nomor 23/MIND/PER/4/2013 tentang perubahan atas Peraturan Menteri Perindustrian Nomor 87/M-IND/PER/2009 tentang Sistem Harmonisasi Global Pengklasifikasian dan Label pada Bahan Kimia terdapat bagaimana cara menyikapi bahan kimia yang berbahaya untuk melindungi kesehatan, keamanan dan keselamatan masyarakat dan lingkungan dari risiko bahan kimia serta perbedaan klasifikasi dan pelabelan bahan kimia yang dapat menghambat kelancaran arus perdagangan maupun pengamanan bahan kimia.

PT. Pupuk Kalimantan Timur merupakan salah satu perusahaan pengekspor pupuk urea dan amoniak terbesar di Indonesia. PT. Pupuk Kalimantan Timur bergerak dalam bidang pembuatan amoniak, pupuk urea dan pupuk NPK. Saat ini PT. Pupuk Kalimantan Timur memiliki 8 unit pabrik yang berada di dalam 1 kawasan, diantaranya Pabrik amoniak dan urea yaitu pabrik 1, pabrik 2, pabrik 3, pabrik 4, pabrik 5, pabrik 1A. Pabrik NPK fusion dan blending, serta Pabrik Boiler batubara. PT. Pupuk Kalimantan Timur memiliki kapasitas produksi urea sebesar 4.135.000 ton/tahun dan amoniak sebesar 3.335.000 ton/tahun.

Urea memiliki kandungan nitrogen $46 \%$ Urea dibuat dari reaksi antara amoniak dengan karbon dioksida dalam suatu proses kimia menjadi urea padat dalam bentuk prill (1-3mm) dan granul (2$4 \mathrm{~mm}$ ) yang keduanya diproduksi oleh PT. Pupuk Kalimantan Timur. PT. Pupuk Kalimantan Timur memasarkan Amoniak dalam bentuk cair pada suhu $-33^{\circ} \mathrm{C}$ dengan kemurnian minimal 99,5\% dan campuran berupa air maksimal 0,5\%. Amoniak dibuat dari bahan baku gas bumi 
yang direaksikan dengan udara dan uap air yang diproses pada suhu dan tekanan tinggi secara bertahap melalui beberapa reaktor yang mengandung katalis.

Hampir setiap bagian dari produksi di PT. Pupuk Kalimantan Timur berhubungan dengan bahan-bahan kima berbahaya baik sebagai bahan baku, proses produksi dan hasil produksi berupa amoniak dan urea. PT. Pupuk Kalimantan Timur telah menerapkan Globally Harmonized System (GHS) sebagai salah satu pengendalian bahan kimia pada tahun 2010 sesuai dengan dikeluarkannya Peraturan Menteri Perindustrian Nomor 87/M-IND/PER/2009 tentang Sistem Harmonisasi Global Pengklasifikasian dan Label pada Bahan Kimia. Pada penelitian ini peneliti tertarik melakukan penelitian tentang evaluasi penerapan Globally Harmonized System (GHS) di PT. Pupuk Kalimantan Timur.

\section{METODE}

Penelitian yang dilaksanakan adalah penelitian observasional. Berdasarkan tempat penelitian, penelitian ini merupakan penelitian lapangan yang dilakukan dengan rancang bangun cross sectional, karena pengamatan dilakukan pada suatu periode tertentu. Menurut analisis, penelitian ini bersifat deskriptif karena bertujuan untuk membuat gambaran atau deskripsi tentang suatu keadaan secara objektif.

Objek penelitian adalah GHS yang dikomunikasikan pada Safety Data Sheet (SDS)/ Lembar Data Keselamatan (LDK) dan pelabelan pada pabrik proses produksi dan pada bahan-bahan kimia yang digunakan dalam proses produksi di PT. Pupuk Kalimantan Timur. Jumlah bahan kimia di gudang sebanyak 57 bahan kimia. Populasi penelitian adalah tenaga kerja di bagian gudang bahan kimia yang berjumlah 18 orang dan safety officer dari 8 pabrik yang berjumlah 24 orang.

Besar sampel ditentukan dengan teknik purposive sampling yaitu pengambilan sampel secara sengaja sesuai dengan persyaratan sampel yang diperlukan (Notoatmodjo, 2010), sehingga diperoleh sampel sebanyak 3 orang pada bagian gudang bahan kimia dan 8 orang safety officer dari 8 pabrik guna diwawancarai mengenai penerapan GHS di PT. Pupuk Kalimantan Timur.

Data diperoleh dengan cara observasi lapangan yaitu pengamatan secara langsung dengan menggunaan instrumen checklist untuk mendapatkan data meliputi penerapan GHS, peninjauan SDS/LDK, dan peninjauan label bahan kimia di gudang bahan kimia dan pabrik di PT. Pupuk Kalimantan Timur. Selain observasi, data diperoleh melalui 
wawancara dengan pihak staff $\mathrm{K} 3$ atau P2K3, tenaga kerja khususnya di bagian gudang bahan kimia, dan pekerja di bagian pabrik untuk mengetahui lebih jauh tentang penerapan komunikasi bahaya melalui GHS, peninjauan SDS/LDK, dan peninjauan label bahan kimia serta kecelakaan yang pernah dialami sebelum dan sesudah penerapan GHS. Wawancara dilakukan setelah responden diberi penjelasan sebelum penelitian dan menandatangani informed consent.

Instrumen yang digunakan dalam penelitian ini merupakan pedoman wawancara dan checklist guna mengobservasi GHS yang terbagi menjadi checklist SDS/LDK pada pabrik produksi, checklist SDS/LDK pada bahan kimia di gudang, checklist pelabelan pada pabrik produksi, dan checklist pelabelan pada bahan kimia di gudang. Hasil dari checklist tersebut selanjutnya dimasukkan dalam kategori menurut Sudjana (2002). Untuk variabel Penyediaan dan Pemasangan SDS/LDK, variabel $\mathrm{P}=$ panjang kelas dengan rentang sebesar 19 (selisih nilai tertinggi dan nilai terendah) dan banyak kelas sebanyak 3 kelas (baik, sedang, kurang) didapatkan panjang kelas sebesar 6. Dengan menggunakan $P=6$ maka didapatkan nilai variabel penyediaan dan pemasangan SDS/LDK adalah kategori baik $=13-19=\geq 68 \%$, sedang $=7-12=$ $32 \%-67 \%$, kurang $=0-6=\leq 31 \%$.

Untuk variabel Penyediaan dan Pemasangan Label, variabel $\mathrm{P}=$ panjang kelas dengan rentang sebesar 9 (selisih nilai tertinggi dan nilai terendah) dan banyak kelas sebanyak 3 kelas (baik, sedang, kurang) didapatkan panjang kelas sebesar 3. Dengan menggunakan $\mathrm{P}=3$ maka didapatkan nilai interval variabel penyediaan dan pemasangan label adalah diantaranya kategori baik $=7-9=\geq 78 \%$, sedang $=3-6=34 \%-77 \%$, kurang $=0-3$ $=\leq 33 \%$.

Setelah mendapatkan nilai dari masing-masing variabel, mulai dari klasifikasi bahan kimia, penyediaan SDS/LDK dan penyediaan label. Dapat diketahui tingkat penerapan GHS di PT. Pupuk Kalimantan Timur sebagai berikut. Variabel $\mathrm{P}=$ panjang kelas dengan rentang sebesar 34 (akumulasi nilai tertinggi dari variabel klasifikasi bahan kimia, penyediaan SDS/LDK dan penyediaan label) dan banyak kelas sebanyak 3 kelas (baik, cukup, buruk) didapatkan panjang kelas sebesar 11. Dengan menggunakan P = 11 maka didapatkan nilai interval adalah dengan kategori baik $=23-34=>67 \%$, Cukup $=12-22=33 \%-67 \%$, Kurang $=0$ $11=\leq 32 \%$ 
Kemudian data dianalisis decara deskriptif sesuai dengan kategori yang ditentukan dan diolah dengan menggunakan tabulasi dan frekuensi.

\section{HASIL DAN PEMBAHASAN}

Menurut Peraturan Direktur Jendral Basis Industri Manufaktur tentang Sistem Harmonisasi Global Klasifikasi dan Label pada Bahan Kimia menyebutkan pada pasal 1 ayat 2, Globally Harmonized System of Clasification and Labelling of Chemicals atau yang disingkat dengan GHS adalah Sistem Global untuk standarisasi kriteria dan mengharmonisasikan sistem klasifikasi bahaya bahan kimia serta mengkomunikasikan informasi tersebut pada safety data sheet (SDS)/ lembar data keselamatan dan label bahan kimia (LDK).

\section{Globally Harmonized System} (GHS) sudah terdapat dalam Peraturan Menteri Perindustrian Nomor 87/MIND/PER/9/2009 tentang Globally Harmonized System Klasifikasi dan Label pada Bahan Kimia dan untuk penerapan GHS itu sendiri sudah terdapat dalam Peraturan Direktur Jendral Industri Agro dan Kimia Nomor 21/IAK/PER/4/2010 tentang Petunjuk Teknis Penerapan Globally Harmonized System Klasifikasi dan Label pada Bahan Kimia.
Beberapa manfaat manfaat dalam melaksanakan Globally Harmonized System, diantaranya adalah efisiensi peraturan bahan kimia, sebagai fasilitas dalam hal jual-beli bahan kimia, mengurangi pengeluaran, informasi bahaya yang konsisten, informasi tanggap darurat akibat insiden bahan kimia, dapat mengamankan bahan kimia dalam hal transportasi, pemakaian, dan penanganan. (Lesmana, 2007)

Globally Harmonized System dapat mencakup semua bahaya bahan kimia di tempat kerja dan dapat digunakan untuk mencakup bahan kimia yang ada di tempat kerja, transportasi, dan konsumen. Target diciptakan Globally Harmonized System adalah untuk pekerja, pekerja transportasi, tangap darurat dan pemakai. Dalam melakukan Globally Harmonized System terdapat dua poin penting dalam hal penerapan. Poin penting tersebut adalah klasifikasi bahaya bahan kimia (Safety Data Sheets) dan komunikasi bahaya (Labels). Penerapan Globally Harmonized System di PT. Pupuk Kalimantan Timur meliputi penyediaan SDS/LDK pada bahan kimia di gudang bahan kimia, penyediaan SDS/LDK pada pabrik produksi, penyediaan dan pemasangan label pada bahan kimia di gudang bahan kimia, serta penyediaan dan pemasangan 
label pada bahan kimia pada pabrik produksi.

\section{Penyediaan Safety Data Sheet pada}

\section{Bahan Kimia}

Penyediaan Safety Data Sheet

(SDS) atau Lembar Data Keselamatan Bahan (LDKB) harus selalu ada, hal tersebut dilakukan untuk mengidentifikasi bahan kimia yang terdapat dalam produk yang digunakan dan memudahkan dalam mengidentifikasi setiap bahaya yang terkait dengan penggunaan bahan kimia tersebut dan dapat memudahkan orang lain dalam penanganan bahan kimia.

Implementasi GHS memandatkan penggunaan simbol/ piktogram sesuai standar GHS, artinya Indonesia juga akan menggunakan dan memiliki standar dalam hal simbol bahaya. Adapun simbol yang digunakan di Indonesia umumnya mengadopsi dari beberapa standar seperti EU. Sedangkan pada saatnya GHS diimplementasikan secara menyeluruh maka Indonesia akan mengadopsi simbol/ piktogram GHS. Simbol/piktogram GHS sangat mudah difahami dan memiliki standar pewarnaan yang sangat mudah dikenali. Hal ini akan membantu pekerja/konsumen dalam mengidentifikasi bahaya yang ada beserta perlindungan apa saja yang harus digunakan pada saat bekerja dengan bahan kimia terkait. (Lesmana, 2007)
Jenis SDS/ LDKB yang digunakan pada bahan kimia ini merupakan SDS/LDK dari supplier asal bahan kimia tersebut. Berikut merupakan hasil observasi penyediaan SDS/LDKB bahan kimia di PT. Pupuk Kalimantan Timur.

Tabel 1. Hasil Checklist Penyediaan Safety Data Sheet pada bahan kimia di PT. Pupuk Kalimantan Timur Juni 2016

\begin{tabular}{|c|c|c|c|c|}
\hline No & Kriteria & (n) & Skor & $(\%)$ \\
\hline 1. & Tersedia & 20 & 0,35 & 1,84 \\
\hline 2. & $\begin{array}{l}\text { Berisikan } 16 \\
\text { section isi LDK }\end{array}$ & 16 & 0,28 & 1,47 \\
\hline 3. & $\begin{array}{l}\text { Identifikasi } \\
\text { senyawa }\end{array}$ & 20 & 0,35 & 1,84 \\
\hline 4. & $\begin{array}{l}\text { Identifikasi } \\
\text { bahaya }\end{array}$ & 19 & 0.33 & 1,73 \\
\hline 5. & Komposisi & 18 & 0,31 & 1,63 \\
\hline 6. & Tindakan P3K & 20 & 0,35 & 1,84 \\
\hline 7. & $\begin{array}{l}\text { Tindak } \\
\text { pemadaman } \\
\text { kebakaran }\end{array}$ & 20 & 0,35 & 1,84 \\
\hline 8. & $\begin{array}{l}\text { Tindakan } \\
\text { penanggulangan } \\
\text { jika terjadi } \\
\text { tumpahan dan } \\
\text { kebocoran }\end{array}$ & 18 & 0,31 & 1,63 \\
\hline 9. & $\begin{array}{l}\text { Penanganan dan } \\
\text { penyimpanan }\end{array}$ & 20 & 0,35 & 1,84 \\
\hline 10. & $\begin{array}{l}\text { Kontrol } \\
\text { paparan/perlind } \\
\text { ungan diri }\end{array}$ & 20 & 0,35 & 1,84 \\
\hline 11. & $\begin{array}{l}\text { Sifat fisika dan } \\
\text { kimia }\end{array}$ & 19 & 0,33 & 1,73 \\
\hline 12. & $\begin{array}{l}\text { Stabilitas dan } \\
\text { reaktifitas }\end{array}$ & 18 & 0,31 & 1,63 \\
\hline 13. & $\begin{array}{l}\text { Informasi } \\
\text { toksikologi }\end{array}$ & 16 & 0,28 & 1,47 \\
\hline 14. & $\begin{array}{l}\text { Informasi } \\
\text { ekologi }\end{array}$ & 16 & 0,28 & 1,47 \\
\hline 15. & $\begin{array}{l}\text { Pembuangan } \\
\text { limbah }\end{array}$ & 17 & 0,29 & 1,52 \\
\hline 16. & $\begin{array}{l}\text { Pertimbangan } \\
\text { pembuangan/pe } \\
\text { musnahan }\end{array}$ & 17 & 0,29 & 1,52 \\
\hline
\end{tabular}




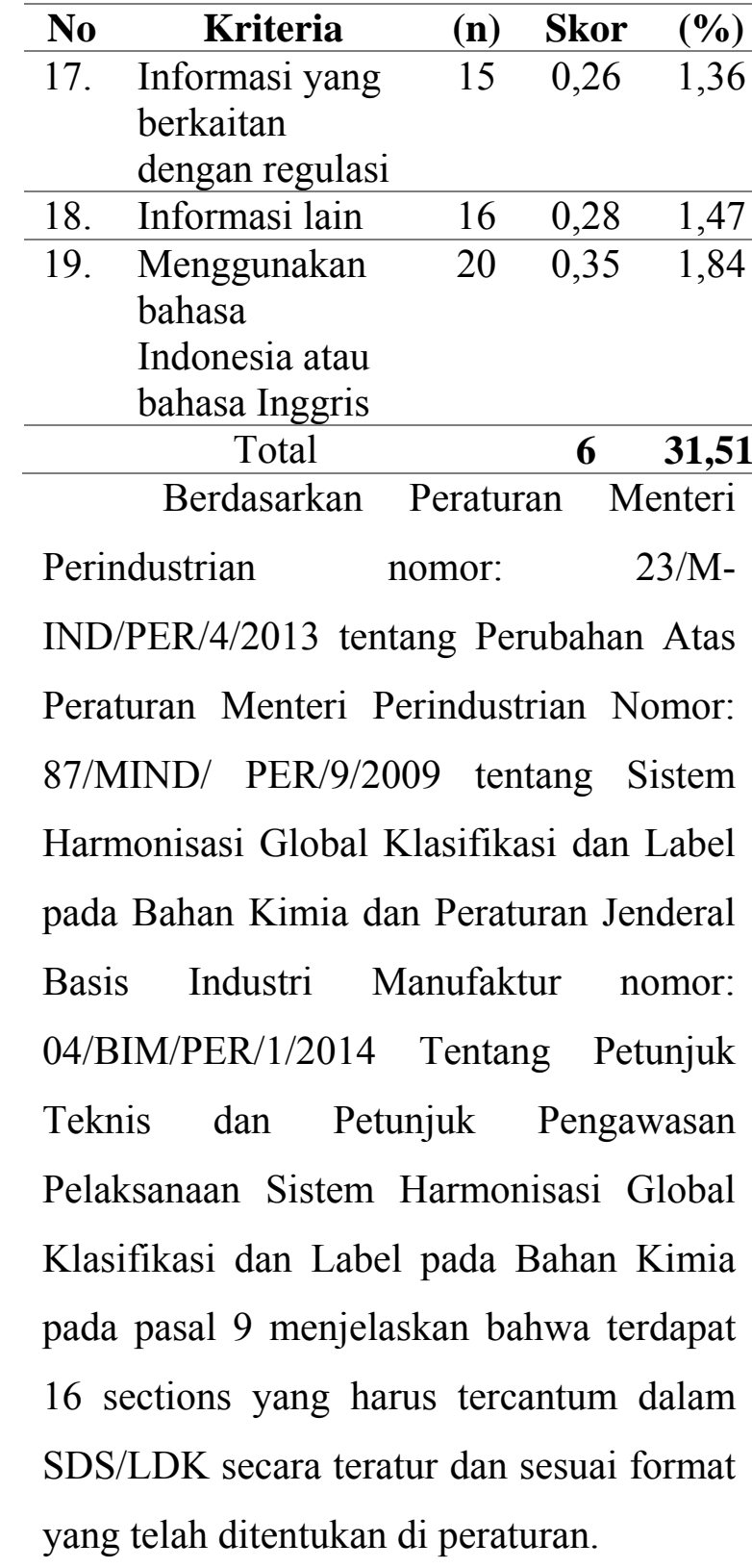

Dari hasil observasi penyediaan SDS/LDK bahan kimia di gudang menghasilkan bahwa penyediaan SDS/LDK bahan kimia di gudang masih belum lengkap, hanya terdapat 20 SDS dari 57 bahan kimia yang ada di gudang bahan kimia PT. Pupuk Kalimantan Timur, masih banyak bahan kimia yang tidak dilengkapi dengan SDS/LDK disebabkan karena tempat menaruh SDS/LDK di gudang yang kurang dan tidak tersusun dengan rapi sehingga banyak SDS/LDK yang tercecer dan akhirnya hilang. Isi dari 20 SDS tersebut yang berisikan 16 sections yaitu sebanyak 16 bahan dan hanya 3 bahan yang menggunakan Bahasa Indonesia dalam menuliskan isi SDS sedangkan 17 lainnya menggunakan Bahasa Inggris.

Menurut Siswanto (1991), LDK hendaknya disimpan disuatu tempat yang dekat dengan tempat kerja karyawan dan selalu tersedia pada setiap shift. Dari hasil observasi, peletakkan SDS/LDK di gudang bahan kimia sudah tepat yaitu berada di dalam rak kaca di didekat pintu antara gudang chemical dan gudang catalist. SDS/ LDK yang berasal dari supplier ini dikumpulkan dan dimasukan kedalam box merah dari bahan plastik yang tujuannya agar LDK tidak mudak rusak, namun masih kurang rapi dalam penyusunannya sehingga menyulitkan ketika hendak mencari LDK suatu bahan tertentu, terlebih pada saat keadaan darurat. Secara keseluruhan dari 19 kriteria, penyediaan SDS di PT. Pupuk Kalimantan Timur mendapatkan skor 6 atau 31,51\% yang termasuk dalam kategori kurang.

\section{Penyediaan Safety Data Sheet pada}

\section{Bahan Kimia}

Selain pada gudang bahan kimia, di pabrik proses produksi yang merupakan 
tempat langsung berinteraksi antara pekerja dengan bahan kimia juga harus disediakan SDS/LDK untuk mencegah kecelakaan akibat penanganan bahan kimia yang kurang tepat. Berikut merupakan hasil observasi penyediaan SDS/LDKB pada pabrik di PT. Pupuk Kalimantan Timur.

Tabel 2. Hasil Checklist Penyediaan Safety Data Sheet pada bahan kimia di PT. Pupuk Kalimantan Timur Juni 2016

\begin{tabular}{|c|c|c|c|c|}
\hline No & Kriteria & (n) & Skor & (\%) \\
\hline 1. & Tersedia & 57 & 1 & 5,26 \\
\hline 2. & $\begin{array}{l}\text { Berisikan } 16 \\
\text { section isi LDK }\end{array}$ & 57 & 1 & 5,26 \\
\hline 3. & $\begin{array}{l}\text { Identifikasi } \\
\text { senyawa }\end{array}$ & 57 & 1 & 5,26 \\
\hline 4. & $\begin{array}{l}\text { Identifikasi } \\
\text { bahaya }\end{array}$ & 57 & 1 & 5,26 \\
\hline 5. & Komposisi & 57 & 1 & 5,26 \\
\hline 6. & Tindakan P3K & 57 & 1 & 5,26 \\
\hline 7. & $\begin{array}{l}\text { Tindak } \\
\text { pemadaman } \\
\text { kebakaran }\end{array}$ & 57 & 1 & 5,26 \\
\hline 8. & $\begin{array}{l}\text { Tindakan } \\
\text { penanggulangan } \\
\text { jika terjadi } \\
\text { tumpahan dan } \\
\text { kebocoran }\end{array}$ & 57 & 1 & 5,26 \\
\hline 9. & $\begin{array}{l}\text { Penanganan dan } \\
\text { penyimpanan }\end{array}$ & 57 & 1 & 5,26 \\
\hline 10. & $\begin{array}{l}\text { Kontrol } \\
\text { paparan/perlind } \\
\text { ungan diri }\end{array}$ & 57 & 1 & 5,26 \\
\hline 11. & $\begin{array}{l}\text { Sifat fisika dan } \\
\text { kimia }\end{array}$ & 57 & 1 & 5,26 \\
\hline 12. & $\begin{array}{l}\text { Stabilitas dan } \\
\text { reaktifitas }\end{array}$ & 57 & 1 & 5,26 \\
\hline 13. & $\begin{array}{l}\text { Informasi } \\
\text { toksikologi }\end{array}$ & 57 & 1 & 5,26 \\
\hline 14. & $\begin{array}{l}\text { Informasi } \\
\text { ekologi }\end{array}$ & 57 & 1 & 5,26 \\
\hline 15. & $\begin{array}{l}\text { Pembuangan } \\
\text { limbah }\end{array}$ & 57 & 1 & 5,26 \\
\hline
\end{tabular}

\begin{tabular}{llccc}
\hline No & \multicolumn{1}{c}{ Kriteria } & (n) & Skor & $\mathbf{( \% )}$ \\
\hline 16. & $\begin{array}{l}\text { Pertimbangan } \\
\text { pembuangan/pe } \\
\text { musnahan }\end{array}$ & 57 & 1 & 5,26 \\
\hline 17. & $\begin{array}{l}\text { Informasi yang } \\
\text { berkaitan } \\
\text { dengan regulasi }\end{array}$ & 57 & 1 & 5,26 \\
\hline 18. & Informasi lain & 57 & 1 & 5,26 \\
\hline 19. & $\begin{array}{l}\text { Menggunakan } \\
\text { bahasa } \\
\text { Indonesia atau } \\
\text { bahasa Inggris }\end{array}$ & 57 & 1 & 5,26 \\
\hline \multicolumn{1}{c}{ Total } & & 19 & $\mathbf{1 9 , 9 4}$ \\
\hline
\end{tabular}

Dari total 57 bahan kimia yang digunakan PT. Pupuk Kalimantan Timur sebagai bahan baku dan didistribusikan ke pabrik mendapat skor 19 dan persentase 99,94\% yang tergolong dalam kategori baik karena telah dilengkapi dengan SDS/ LDKB yang dikeluarkan oleh PT. Pupuk Kalimantan Timur sendiri. SDS/LDKB tersebut berbentuk sebuah buku, namun disimpan di kantor pada masing-masing pabrik sehingga tidak mudak untuk dijangkau oleh pekerja.

Terdapat perbedaan yang cukup signifikan antara hasil penilaian dari penyediaan SDS bahan kimia di gudang bahan kimia dan penyediaan SDS pada pabrik di PT. Pupuk Kalimantan Timur. Penyediaan SDS/ LDK pada pabrik yang sudah dalam berbentuk buku yang dikeluarkan oleh Departemen K3 dan sudah menyesuaikan 16 sections serta menggunakan bahasa indonesia sehingga lebih mudah untuk dipahami. Namun selain piktogram dan simbol GHS, masih 
terdapat SDS/LDK milik PT. Pupuk Kalimantan timur yang menggunakan lambang NFPA, hal ini dilakukan karena PT. Pupuk Kalimantan Timur sendiri masih melakukan peralihan dari NFPA ke GHS.

Selain itu, buku MSDS Pupuk Kaltim disimpan jauh dari pabrik proses produksi yaitu diletakkan di kantor pada masing-masing pabrik. Peletakkan SDS/LDK yang jauh dari tempat kerja menyebabkan pekerja tidak dapat mengakses SDS/LDK tersebut dengan mudah sehingga berpotensi kecelakaan akibat salah penanganan bahan kimia. Selain SDS/LDK berbentuk buku, terdapat SDS/LDK bahan-bahan tertentu berbentuk baliho yang dipasang disejumlah sudut jalan pada pabrik yang memuat berbagai informasi penting tentang bahaya dan penanganan bahan kimia tertentu Baliho SDS tersebut dimaksudkan sebagai pengganti SDS/LDK yang belum tersedia di area pabrik, namun baliho tersebut masih kurang menyeluruh karena belum mencakup semua bahan kimia dan 16 sections SDS/LDK.

\section{Penyediaan dan Pemasangan Label pada Bahan Kimia}

Label adalah keterangan mengenai bahan kimia yang berbentuk piktogram bahaya atau simbol, tulisan atau kombinasi keduanya atau bentuk lain yang juga berisi informasi identitas bahan kimia atau produk, identitas produsen atau pemasok, serta klasifikasi bahan kimia. Berdasarkan hasil observasi terdapat dua jenis pelabelan, yaitu yang sudah terdapat pada kemasan produk dari supplier dan yang dibuat oleh PT. Pupuk Kalimantan Timur. Dibawah merupakan hasil observasi penyediaan label pada bahan kimia dari supplier untuk bahan baku produksi di PT. Pupuk Kalimantan Timur.

Tabel 3. Hasil Checklist Penyediaan dan Pemasangan Label di Gudang Bahan Kimia PT. Pupuk Kalimantan Timur Juni 2016

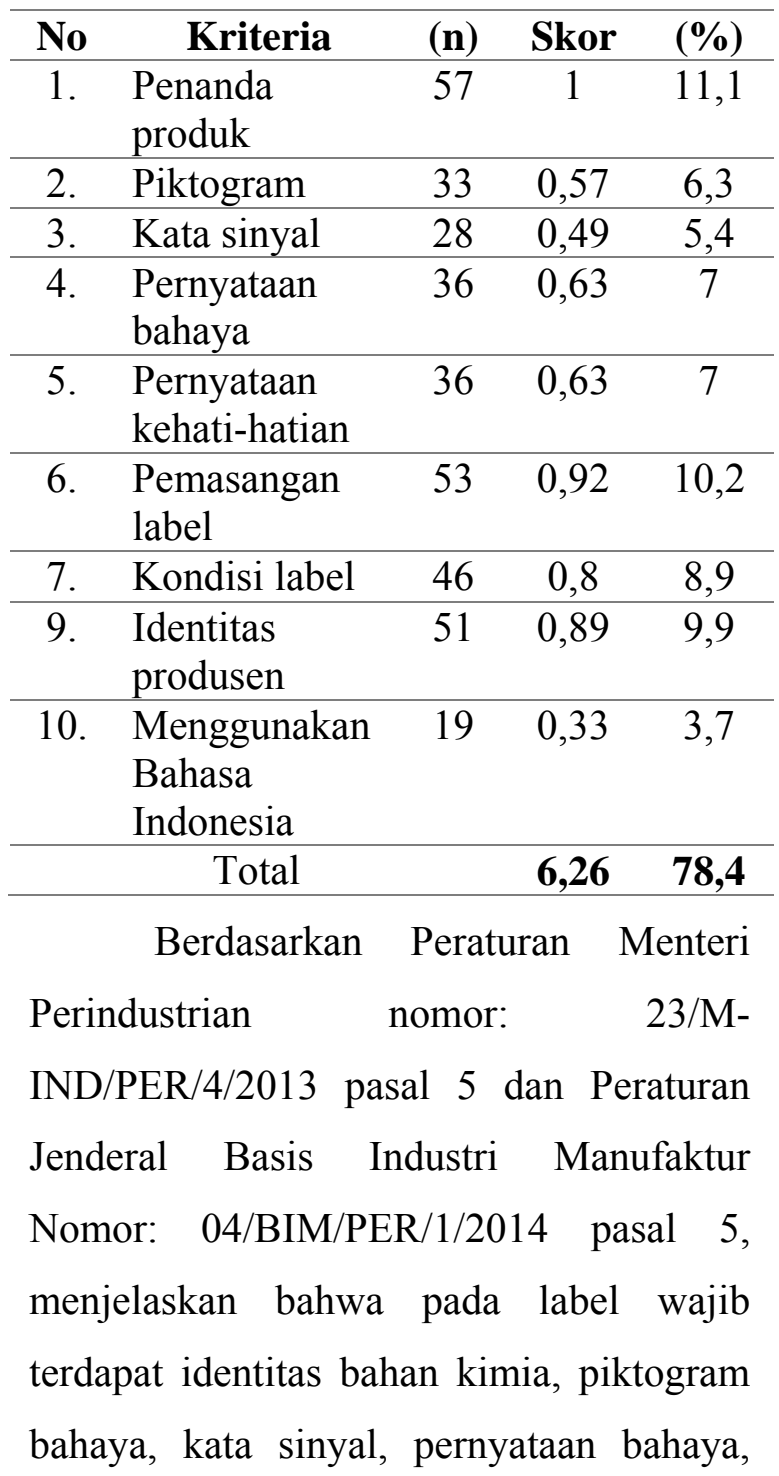


pernyataan kehati-hatian, dan identitas produsen dan/atau pemasok atau importir.

Dari hasil observasi penyediaan dan pemasangan label pada bahan kimia di PT. Pupuk Kalimantan Timur mendapatkan skor 6,26 dan persentase sebesar $78,4 \%$ dari total semua kriteria tersebut terpenuhi. Semua bahan kimia di PT. Pupuk Kalimantan Timur telah terpasang label, namun hanya 33 bahan kimia dari total 57 bahan yang sesuai menggunakan piktogram GHS.

Masih terdapat bahan kimia yang dalam pelabelannya digabung antara piktogram GHS dengan label NFPA, hanya menggunakan simbol NFPA saja ataupun yang tidak memiliki simbol sama sekali. Bahkan hasil produk dari PT. Pupuk Kalimantan Timur sendiri, seperti pupuk urea Daun Buah, urea Pupuk Indonesia, NPK Pelangi dan NPK Pelangi Agro pada kemasannya masih belum memiliki label sesuai dengan standar GHS. Kondisi label pada bahan kimia tergolong baik dan dapat terbaca dengan jelas.

Untuk memudahkan dalam penyimpanan dan mengenali sifat-sifat bahan kimia di gudang, dibuat pelabelan tambahan yang digantung diatas, namun dalam penempatannya masih banyak yang belum sesuai karena bahan di dalam gudang yang sangat banyak sehingga menyebabkan bahan-bahan kimia ditaruh sembarangan.

Penyediaan dan Pemasangan Label di Pabrik

Selain pada bahan kimia, di pabrik khususnya pada tangki atau tempat menyimpan bahan kimia lainnya di pabrik juga harus disediakan dan dipasangkan label untuk mengidentifikasi bahaya serta memberikan informasi tipe bahaya, pengelolaan dan penananganan kepada orang yang berinteraksi dengan bahan tersebut. Oleh karena itu PT. Pupuk Kalimantan Timur membuat dan memasang label pada tangki penyimpanan bahan kimia di pabrik sesuai dengan klasifikasinya. Berikut merupakan hasil observasi penyediaan SDS/LDKB di pabrik PT. Pupuk Kalimantan Timur.

Tabel 4. Hasil Checklist Penyediaan dan Pemasangan Label di Pabrik PT. Pupuk Kalimantan Timur Juni 2016

\begin{tabular}{clccc}
\hline No & \multicolumn{1}{c}{ Kriteria } & (n) & Skor & $\mathbf{( \% )}$ \\
\hline 1. & $\begin{array}{l}\text { Penanda } \\
\text { produk }\end{array}$ & 57 & 1 & 11,1 \\
\hline 2. & Piktogram & 57 & 1 & 11,1 \\
\hline 3. & Kata sinyal & 57 & 1 & 11,1 \\
\hline 4. & $\begin{array}{l}\text { Pernyataan } \\
\text { bahaya }\end{array}$ & 57 & 1 & 11,1 \\
\hline 5. & $\begin{array}{l}\text { Pernyataan } \\
\text { kehati-hatian }\end{array}$ & 57 & 1 & 11,1 \\
\hline 6. & $\begin{array}{l}\text { Pemasangan } \\
\text { label }\end{array}$ & 57 & 1 & 11,1 \\
\hline 7. & Kondisi label & 57 & 1 & 11,1 \\
\hline 9. & $\begin{array}{l}\text { Identitas } \\
\text { produsen }\end{array}$ & - & - & - \\
\hline
\end{tabular}




\begin{tabular}{llccc}
\hline No & \multicolumn{1}{c}{ Kriteria } & (n) & Skor & $\mathbf{( \% )}$ \\
\hline 10. & Menggunakan & 57 & 1 & 11,1 \\
& $\begin{array}{l}\text { Bahasa } \\
\text { Indonesia }\end{array}$ & & & \\
\hline \multicolumn{1}{c}{ Total } & & $\mathbf{8}$ & $\mathbf{8 8 , 8}$ \\
\hline
\end{tabular}

Berdasarkan penilaian penyediaan dan pemasangan label di pabrik PT. Pupuk Kalimantan Timur semua kriteria dipenuhi kecuali kriteria identitas produsen, karena yang membuat adalah dari PT. Pupuk Kalimantan Timur sendiri atas dasar kepentingan dan keamanan produksi. Penyediaan dan pemasangan label di pabrik PT. Pupuk Kalimantan Timur mendapat skor 8 dan persentase sebesar $88,8 \%$ yang termasuk dalam kategori baik.

Label yang dimaksudkan disini adalah yang label yang terdapat pada tangki maupun tempat penyimpanan bahan kimia lainnya yang berada di pabrik yang merupakan sebagai tempat proses produksi utama. Label tersebut dibuat oleh PT. Pupuk Kalimantan Timur atas dasar kepentingan dan keamanan produksi. Berdasarkan hasil observasi, terdapat 8 dari 9 kriteria yang sudah sesuai dengan standar GHS.

Kondisi label dalam keadaaan yang cukup baik, dapat terlihat dengan jelas dan menggunakan bahan yang tidak mudah rusak, yaitu lambang piktogram di cat pada tangki dan informasi lainnya dibuat pada standing label yang terbuat dari alumunium. Kriteria yang tidak terpenuhi adalah kriteria identitas produsen yang tidak dimuat dalam pelabelan karena label tersebut dibuat dan digunakan sendiri oleh PT. Pupuk Kalimantan Timur pada tangki penyimpanan bahan kimia di pabrik.

\section{Tingkat Penerapan Globally Harmonized System Secara Keseluruhan di PT. Pupuk Kalimantan Timur}

Secara keseluruhan tingkat penerapan Globally Harmonized System di PT. Pupuk Kalimantan Timur yaitu sistem klasifikasi bahan kimia yang dikomunikasikan melalui penyediaan Safety Data Sheet atau lembar data keselamatan, serta penyediaan dan pemasangan label pada bahan kimia di PT. Pupuk Kalimantan Timur dapat tergambar pada tabel hasil penelitian dibawah ini:

Tabel 5. Tingkat Penerapan Globally Harmonized System Secara Keseluruhan di PT. Pupuk Kalimantan Timur

\begin{tabular}{|c|c|c|c|}
\hline No & Penerarapan GHS & Skor & $(\%)$ \\
\hline 1. & $\begin{array}{l}\text { Penyediaan dan } \\
\text { pemasangan } \\
\text { SDS/LDK pada bahan } \\
\text { kimia di PT. Pupuk } \\
\text { Kalimantan Timur }\end{array}$ & 6 & 10,71 \\
\hline 2. & $\begin{array}{l}\text { Penyediaan dan } \\
\text { pemasangan } \\
\text { SDS/LDK di pabrik } \\
\text { PT. Pupuk } \\
\text { Kalimantan Timur }\end{array}$ & 19 & 33,92 \\
\hline 3. & $\begin{array}{l}\text { Penyediaan dan } \\
\text { pemasangan label } \\
\text { pada bahan kimia di } \\
\text { PT. Pupuk } \\
\text { Kalimantan Timur }\end{array}$ & 6,26 & 11,17 \\
\hline 4. & $\begin{array}{l}\text { Penyediaan dan } \\
\text { pemasangan label }\end{array}$ & 8 & 14,28 \\
\hline
\end{tabular}




\begin{tabular}{llll}
\hline No & Penerarapan GHS & Skor & (\%) \\
pada bahan kimia di & & \\
& PT. Pupuk \\
& Kalimantan Timur & & \\
\hline Total & $\mathbf{3 9 , 2 6}$ & $\mathbf{7 0 , 0 8}$ \\
\hline
\end{tabular}

Dari hasil perolehan penilaian ketiga kriteria secara keseluruhan yaitu harmonisasi penerapan klasifikasi bahan kimia yang dikomunikasikan melalui penyediaan Safety Data Sheet dan penyediaan dan pemasangan label pada bahan kimia, maka dapat diketahui tingkat penerapan GHS pada bahan kimia di PT. Pupuk Kalimantan Timur yang diperoleh sebesar 70,08 \%. Hal tersebut menunjukkan bahwa penerapan Globally Harmonized System pada bahan kimia di PT. Pupuk Kalimantan Timur terbilang BAIK. Skor didapatkan dari hasil penilaian observasi berdasarkan kriteria yang sudah ditentukan, sedangkan presentase didapatkan dari hasil bagi skor dengan total jumlah kriteria dikalikan $100 \%$.

\section{SIMPULAN DAN SARAN}

\section{Penerapan Globally Harmonized}

System di PT. Pupuk Kalimantan Timur termasuk dalam kategori baik (70,08 \%). Pada poin penyediaan dan pemasangan Lembar Data Keselamatan (SDS/LDK) pada bahan kimia PT. Pupuk Kalimantan Timur masih dalam kategori kurang (31,51\%) karena masih banyak bahan kimia di gudang yang tidak dilengkapi dengan SDS/LDK. Sedangkan pada penyediaan dan pemasangan Lembar Data Keselamatan (SDS/LDK) pada pabrik PT. Pupuk Kalimantan Timur termasuk dalam kategori baik (99,94\%), hanya saja penempatan buku SDS/LDK yang jauh dari lokasi tempat kerja.

Pada poin penyediaan dan pemasangan label pada bahan kimia di PT. Pupuk Kalimantan Timur termasuk dalam kategori baik $(78,4 \%)$, namun masih banyak label yang belum menggunakan piktogram GHS, serta penempatan bahan kimia di gudang bahan kimia yang kurang sesuai, sedangkan pada penyediaan dan pemasangan label di pabrik PT. Pupuk Kalimantan Timur termasuk dalam kategori baik $(88,8 \%)$, namun kriteria identitas produsen masih belum sesuai karena belum dicantumkan pada label di area pabrik PT. Pupuk Kalimantan Timur.

\section{DAFTAR PUSTAKA}

Bouloiz, H., Garbolino, E., Tkiouat, M. 2010. Contribution of a systemic modeling approach applied to support risk analysis of a storage unit of chemical products in Morocco, Journal of Loss Prevention in Proces Industries, Vol. 23: Hal. 312-322.

Lesmana, Dimas Satya. 2007. MSDS dan Implementasinya Berdasarkan GHS. Seminar Nasional K3. Bogor: Chemwatch/Chemcare Asia.

Notoatmodjo, S. 2007. Pendidikan dan Perilaku kesehatan. Jakarta: PT.Rineka Cipta. 
Peraturan Dirktur Jenderal Industri Agro dan Kimia Nomor 21/IAK/PER/2010 tentang Petunjuk Teknis Penerapan Sistem Harmonisasi Global Klasifikasi dan Label pada Bahan Kimia

Peraturan Menteri Perindustrian Republik Indonesia Nomor 23/MIND/PER/4/2013 tentang Perubahan atas Peraturan Menteri Perindustrian Republik Indonesia Nomor 87/MIND/PER/9/2009 tentang Sistem Harmonisasi Global Klasifikasi dan Label pada Bahan Kimia

Peraturan Direktur Jendral Basis Industri Manufaktur Nomor 04/BIM/PER/1/2014 tentang Petunjuk Teknis dan Petunjuk Pengawasan Pelaksanaan Sistem Harmonisasi Global Klasifikasi dan Label pada Bahan Kimia

Peraturan Menteri Perindustrian Republik Indonesia Nomor 87/MIND/PER/9/2009 tentang Sistem Harmonisasi Global Klasifikasi dan Label pada Bahan Kimia

Ramli, Soehatman. 2010. Pedoman Praktis Manajemen Risiko Dalam Perspektif K3. Jakarta: Dian Rakyat Undergraduate-8772-6505040047Chapter1.pdf $>$ [6 November 2015]

Siswanto, A., 1991. Bahaya Bahan Kimia. Handout. Surabaya: Bagian Toksikologi Industri Universitas Airlangga.

Sudjana, 2002. Metode Statistika. Edisi 6, Bandung: Tarsinto

Suriya, Kurniawan. 2003. Analisis Hubungan Kadar Fenol Urin Dengan Pajanan Uap Benzena Pada Pekerja Di Suatu Percetakan Di Jakarta. Tesis Magister Sains. Fakultas Kedokteran Universitas Indonesia. Tersedia di $<$ digilib.its.ac.id/public/ITS- 